\title{
Evidence for Agrobacterium-Induced Apoptosis in Maize Cells
}

\author{
Geneviève Hansen \\ Novartis Agribusiness Biotechnology, Inc. (NABRI), 3054 Cornwallis Road, Research Triangle Park, \\ Durham, NC 27709, U.S.A. \\ Accepted 14 February 2000.
}

\begin{abstract}
Agrobacterium spp. can genetically transform most dicotyledonous plant cells whereas many monocot species are recalcitrant to Agrobacterium-mediated transformation. One major obstacle is that co-cultivation of Agrobacterium spp. with plant tissues often results in cell death. Report here is that, in maize tissues, this process resembles apoptosis, with characteristic DNA cleavage into oligonucleosomal fragments and morphological changes. Two anti-apoptotic genes from baculovirus, p35 and iap, had the ability to prevent the onset of apoptosis triggered by Agrobacterium spp. in maize tissues. p35 is reported to act as a direct inhibitor of a certain class of proteases (caspase) whereas iap may act upstream to prevent their activation. This evidence raises the possibility that caspase-like proteases may also be involved in the apoptotic pathway in plant cells.
\end{abstract}

The soil bacterium Agrobacterium tumefaciens has evolved a natural plant-transformation mechanism in which a DNA segment, the T-DNA, located on the tumor-inducing (Ti) or root-inducing ( $\mathrm{Ri}$ ) plasmids travels by a conjugation-like process from the bacterium to the plant nucleus and becomes integrated into the plant's chromosomal DNA. A. tumefaciens provides an excellent route for introducing foreign DNA into most plants (Hansen and Chilton 1999). In addition, transgenic plants frequently contain a simple integration pattern of the transgene. With the access to a wide array of genes with potential for crop improvement, the interest in optimizing the performance of this system and applying it to all crops has intensified.

A major obstacle in Agrobacterium-mediated transformation can be the incompatibility between A. tumefaciens and plant cells. In many cases, phytopathogenic bacteria carry hrp (hypersensitive reaction and pathogenicity) genes whose products are involved in the elicitation of the hypersensitive response (HR) in resistant plants (Baker et al. 1997). In this interaction, a nonhost plant species recognizes the phytopathogen and induces a rapid defense response (HR) that results in localized necrosis at the site of infection and confines further invasion. Tissue necrosis involving T-DNA genes is ob-

Corresponding author: Geneviève Hansen; Novartis Agribusiness Biotechnology, Inc. (NABRI), 3054 Cornwallis Road, Research Triangle Park, Durham, NC 27709, U.S.A.; Telephone: 1-919-541-8685; Fax: 1-919-541-8585; E-mail: genevieve.hansen@ nabri.novartis.com served in certain plant-Agrobacterium spp. interactions (Deng et al. 1995) but the symptoms appear more slowly than in a typical HR and necrosis extends beyond the inoculation site. The necrotic response induced by wide-host-range (De Cleene and De Ley 1976) Agrobacterium strains on grapevines has been ascribed to cell death at the site of inoculation (Yanofsky et al. 1985). In this case, necrosis is blocked by mutations within the virC locus although T-DNA transfer occurs (Yanofsky et al. 1986). It has also been reported that Agrobacterium strains with a disarmed vector used in standard transformation protocols could affect some plant tissues from various species, hindering the recovery of transgenic plants. For instance, exposure of grape embryogenic calli (Vitis vinifera) to diluted Agrobacterium cultures results in tissue necrosis and subsequent death (Perl et al. 1996). This reaction seems to correlate with elevated levels of peroxides and is prevented by the addition of antioxidants such as polyvinylpyrrolidone and dithiothreitol (Perl et al. 1996). In both aspen and poplar, Agrobacterium-induced necrosis is likely caused by an accumulation of ammonium and could be reduced with addition of Ca gluconate in the culture medium (de Block 1990). In the case of maize, recalcitrance to transformation by Agrobacterium spp. is not clear (Chilton 1993; Smith and Hood 1995). T-DNA transfer can occur and the nuclear localization signals carried by the virulence gene products VirD2 and VirE2 involved in T-DNA transfer and integration are recognized in maize cells (Hansen et al. 1994; Zupan et al. 1996). It was suggested that the recalcitrance may reside in a block of T-DNA integration and in the lack of cell division during wound response (Binns and Thomashow 1988; Narasimhulu et al. 1996).

In all multicellular organisms, cell death can occur by necrosis, a passive process involving disruption of membrane integrity and subsequent swelling that results in lysis, or by programmed cell death (PCD), an active process in which the cell directs its own death (Ellis et al. 1991; Goldstein 1997). PCD has been described as occurring in animal cells to remove unwanted cells during development and maintenance of tissues. There are also many examples of PCD in plants occurring as part of tissue development and in the HR triggered by avirulent pathogens (Jones and Dangl 1996; Levine et al. 1996; Greenberg 1997; Gilchrist 1998; Buckner et al. 1998; Pennell and Lamb 1997). The isolation of spontaneous cell death mutants in Arabidopsis and in maize, in which PCD is activated in the absence of pathogens or stress, suggests that PCD is under genetic control in plants, as reported for vertebrates and invertebrates (Greenberg 1997; Gilchrist 1998). 
PCD proceeds through several stages generally implemented by a mechanism involving de novo gene expression. In this cascade of events, the components of the pathway include regulatory proteins that are conserved among vertebrates and invertebrates and a family of cysteine proteases known as caspases because they cleave specific substrates at Asp residues. In addition, cytochrome c release from the mitochondria has been observed and is involved in the activation of caspases. In the final phase, cells undergo extensive structural changes including cell and nuclear shrinkage, chromatin condensation, DNA fragmentation, and disassembly of the nuclear and cytoplasmic networks (Reed 1997; Raff 1998).

Activation of members of the caspase family has been shown to be both necessary and sufficient to trigger apoptosis in animal cells and is considered the final committing step in the pathway (Raff 1998; Kumar and Colussi 1999; Wolf and Green 1999). Synthetic peptide analogs have been developed that specifically inhibit caspase activity and are useful in blocking the cellular apoptosis program in a variety of systems. It has also been reported that apoptosis can be blocked in vertebrates and in invertebrates by two types of antiapoptotic proteins encoded by baculovirus: p35 and inhibitors of apoptosis (IAPs) (Teodoro and Branton 1997; Bump et al. 1995; Miller 1999). p35 isolated from Autographa californica nuclear polyhedrosis virus (AcMNPV) is a broad-spectrum caspase inhibitor that normally blocks apoptosis in SF-21 cells derived from Spodoptera frugiperda (Clem et al. 1991). The second baculovirus gene found to prevent apoptosis, iap, was identified by its ability to functionally substitute for $p 35$ in a complementation assay (Crook et al. 1993; Birnbaum et al. 1994; Clem and Miller 1994). Homologues of baculovirus IAPs have also been identified in eukaryotes and more recently in plants (Cahoon and Klein 1999).

A hypersensitive type of response can be observed when maize cells are exposed to Agrobacterium spp. and may be part of the incompatibility mechanism. In this report, this response is characterized and is shown to have several aspects indicative of apoptosis or PCD. Furthermore, two antiapoptotic genes reported to function efficiently in vertebrates and invertebrates were found to prevent the onset of apoptosis triggered by Agrobacterium spp. in maize cells.

\section{RESULTS}

\section{Sensitivity of maize embryos and embryogenic callus} to Agrobacterium spp.

Maize immature embryos as well as the derived embryogenic callus lines grown in liquid or in solid medium have been used as target tissues for various transformation procedures (Armstrong 1999; Hansen and Wright 1999). In a typical transformation experiment with Agrobacterium spp. as a vector to deliver genes, plant cells suitable for regeneration are co-cultivated with Agrobacterium spp., followed by a procedure to select and regenerate transformed cells. Prolific embryogenic maize cells were thus subjected to inoculation with Agrobacterium spp.. Most embryos and embryogenic callus lines as well as suspension cells did not survive the inoculation with the Agrobacterium tumefaciens strain LBA4404 at a concentration in the range of 0.2 to $1 \times 10^{9}$ cells per $\mathrm{ml}$ (Table 1; Fig. 1A-D). This concentration range and this strain are used in standard transformation experiments (Ishida et al.
1996; Negrotto et al., in press). As illustrated in Figure 1, most embryos treated with Agrobacterium spp. turned brown and did not develop calli from the scutellum on callus initiation medium. Similarly, embryogenic calli turned brown after a treatment with Agrobacterium spp. and did not exhibit proliferating yellow clusters typical of somatic embryos (compare Figure $1 \mathrm{~B}$ and $\mathrm{D}$ ). Cell death was observed even after the transfer of the treated embryogenic calli to a cefotaximecontaining medium 5 to $10 \mathrm{~min}$ after inoculation. Washing the tissues two or three times with tissue culture medium after inoculation did not prevent the reaction. In control experiments, cefotaxime did not cause maize tissues to die.

Variations can exist among genotypes with respect to performance in tissue culture. The effect of Agrobacterium spp.

Table 1. Response of maize suspension cells to co-cultivation with Agrobacterium spp.

\begin{tabular}{|c|c|c|c|c|c|c|c|c|}
\hline \multirow[b]{3}{*}{ Scoring $^{\mathbf{a}}$} & \multicolumn{8}{|c|}{ Incubation time with Agrobacterium spp. } \\
\hline & \multicolumn{4}{|c|}{$0.2 \times 10^{9}$ cells per $\mathrm{ml}$} & \multicolumn{4}{|c|}{$10^{9}$ cells per $\mathrm{ml}$} \\
\hline & $10 \mathrm{~min}$ & $1 \mathrm{~h}$ & $24 \mathrm{~h}$ & $48 \mathrm{~h}$ & $10 \mathrm{~min}$ & $1 \mathrm{~h}$ & $24 \mathrm{~h}$ & $48 \mathrm{~h}$ \\
\hline 2 days & - & + & + & + & + & + & + & ++ \\
\hline 4 days & + & + & + & ++ & + & + & ++ & +++ \\
\hline 7 days & + & ++ & ++ & +++ & + & ++ & ++++ & ++++ \\
\hline No bacteria & - & - & - & - & - & - & - & - \\
\hline
\end{tabular}

${ }^{a}$ Presence or absence of necrosis was scored 2, 4, and 7 days after inoculation with strain LBA4404.

${ }^{\mathrm{b}}$ Relative necrosis intensity: -, no necrosis; +, rare formation of necrosis; ++ , weak necrosis; +++ , strong necrosis; ++++ , very strong necrosis.

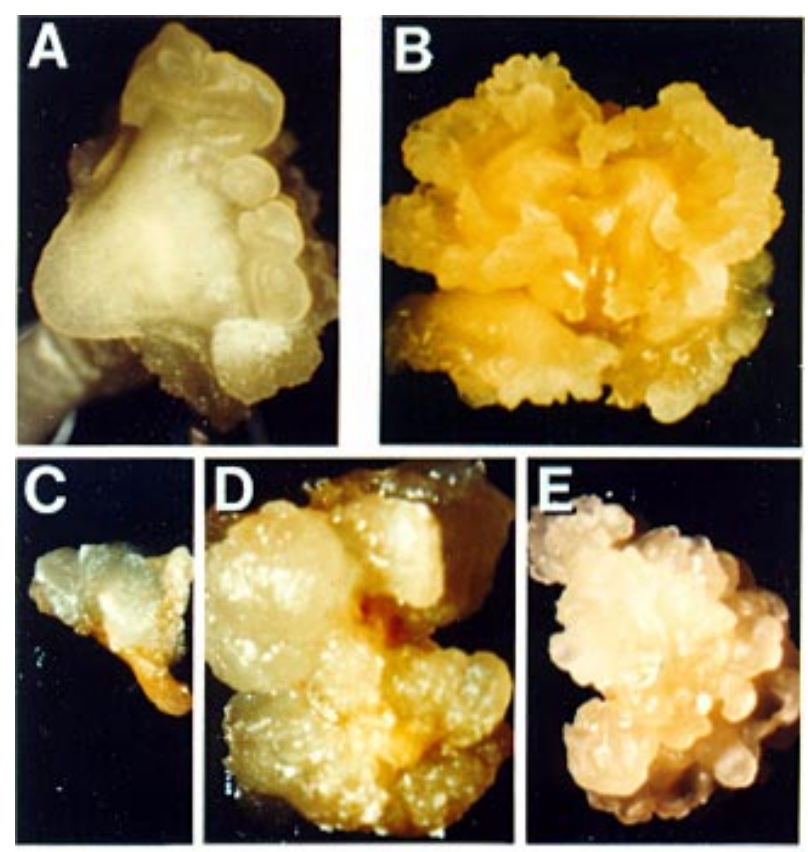

Fig. 1. Sensitivity of maize embryos and embryogenic callus to Agrobacterium spp. Maize immature embryos and callus from the inbred line CG00526 were inoculated with Agrobacterium tumefaciens LBA4404 at a density of $1 \times 10^{9}$ cells per $\mathrm{ml}$ for $5 \mathrm{~min}$, then plated on cefotaximecontaining medium. Pictures were taken 2 weeks after inoculation. A, Nontreated embryo. B, Nontreated callus. C, A. tumefaciens-treated embryo. D, A. tumefaciens-treated callus. E, Callus transgenic for iap treated with $A$. tumefaciens 2 weeks after inoculation. Bar $=10 \mathrm{~mm}$. 
was, however, observed on maize tissues from three different genotypes-CG00526, CG2717, and HE/89. This result indicated that the effect of Agrobacterium spp. on maize tissues appeared to be rather genotype independent.

\section{Cell death mechanism.}

To determine the mechanism of cell death induced by Agrobacterium spp. in maize tissues, genomic DNA was extracted from suspension cells harvested 24 and $48 \mathrm{~h}$ after inoculation with Agrobacterium spp. and subjected to electrophoresis. The study of DNA fragmentation was conducted with suspension cells rather than with embryos because this system offered the possibility of isolating DNA from large batches of cells dividing synchronously. Exposure of maize cells to A. tumefaciens LBA4404 caused the appearance of discrete bands of DNA after electrophoresis of undigested DNA whereas no DNA laddering was detected in cultures grown in the absence of A. tumefaciens LBA4404 (Fig. 2). This pattern is considered an early hallmark of PCD and is associated with the presence of an endogenous nuclease that cleaves chromosomal DNA between individual nucleosomes, producing degraded fragments of approximately $180 \mathrm{bp}$ (Stein and Hansen 1999). Within $24 \mathrm{~h}$ after inoculation, the DNA ladder was detectable on agarose gel and the accumulation of fragments dramatically increased $48 \mathrm{~h}$ after inoculation. As a control, DNA was extracted from tobacco suspension cultures that were in culture for 24 or $48 \mathrm{~h}$ with an Agrobacterium sp. As illustrated in Figure 2, no DNA fragmentation was detected on agarose gel. DNA extracted from an Agrobacterium sp. cultured in the presence or absence of maize cells showed no degradation, indicating that the observed DNA laddering was derived from the maize genome (data not shown).

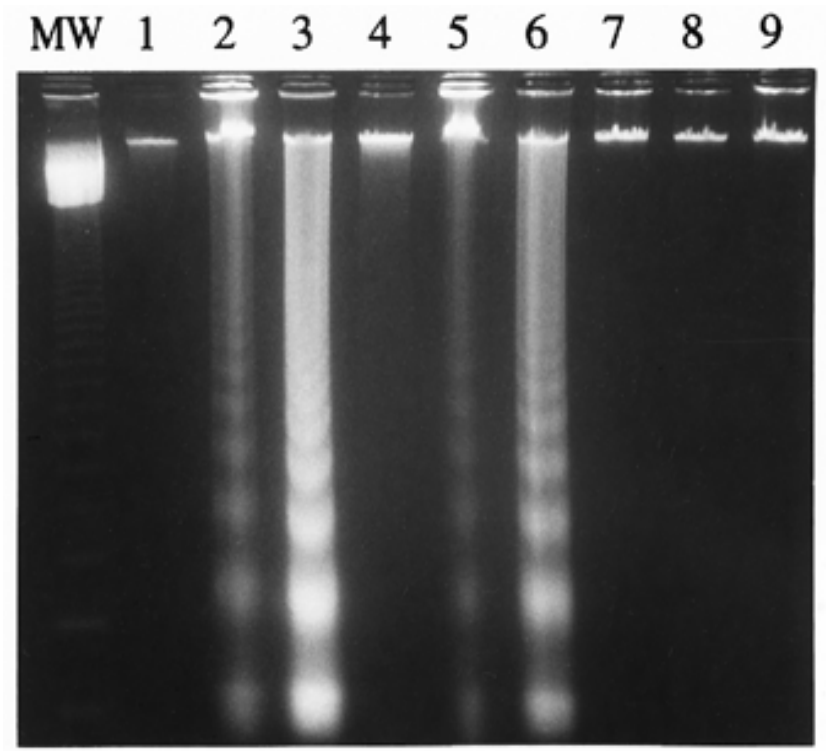

Fig. 2. DNA laddering induced by Agrobacterium spp. in maize suspension cells. Chromosomal DNA was extracted from (lanes 1, 4, 7) untreated plant suspension cells or from suspension cells inoculated with Agrobacterium tumefaciens LBA4404 for (lanes 2, 5, 8) 24 or (lanes 3, 6 , 9) $48 \mathrm{~h}$. Approximately 1 to $2 \mu \mathrm{g}$ of undigested genomic DNA was run on a $2 \%$ agarose gel and stained with ethidium bromide. Lanes 1-3, HE/89 maize cells; lanes 4-6, CG2717 maize cells; lanes 7 and 8, NT1 tobacco cells. Left lane, 123-bp ladder.
No DNA degradation was detected in maize cells pretreated with cycloheximide at a concentration of $40 \mu \mathrm{M} 30$ min prior to the inoculation and washed three times extensively with fresh culture medium. Inoculation of maize cells with Escherichia coli or with autoclaved Agrobacterium spp. cells contained high molecular weight DNA with no evidence of degradation. It was also observed that suspension maize culture in contact with Agrobacterium spp. for $48 \mathrm{~h}$ and washed of Agrobacterium spp. cells failed to induce cell death of fresh culture. DNA fragmentation was also detected in maize tissues after inoculation with Agrobacterium strains cured of the Ti plasmid carrying the virulence functions needed for T-DNA transfer into plant cells. This indicated that the process of genetic transformation by Agrobacterium spp. was not required to trigger cell death (data not shown).

Intranucleosomal DNA cleavage can also be examined by an assay that allows for in situ detection of DNA breaks at the single cell level. This method is based on the labeling of the $3^{\prime}$ ends of DNA strand breaks. As illustrated in Figure 3B, embryo cells treated with Agrobacterium spp. did show some dark precipitates localized in the nuclei whereas no staining could be observed in the control experiment carried out with embryos plated on callus initiation medium (Fig. 3A). Also, maize cells became distorted in shape after exposure to Agrobacterium spp. (Fig. 3B). This morphological change was obvious $24 \mathrm{~h}$ after inoculation. Interestingly, cytological signs of DNA cleavage were observed in embryos treated with Agrobacterium spp. within a few hours of the onset of cell degradation whereas the distortion of maize cells started to be apparent at a later stage.

In several animal models, cytochrome c release from mitochondria into the cytosol is one of the earliest events in apoptosis and is required for the activation of the caspase protease cascade, as well as downstream events including DNA laddering. To track cytochrome c distribution within maize cells, protein extracts were separated into particulate and soluble fractions, containing mitochondrial and cytosolic proteins, respectively, and analyzed by Western blot (immunoblot) with an anti-cytochrome c monoclonal antibody (Stein and Hansen 1999). Maize cells were cultured in the absence or presence of A. tumefaciens LBA4404 for 62,72 , or $88 \mathrm{~h}$. The subcellular distribution of cytochrome $\mathrm{c}$ in these cultures is shown in Figure 4. In the noninfected cultures, most of the cytochrome c

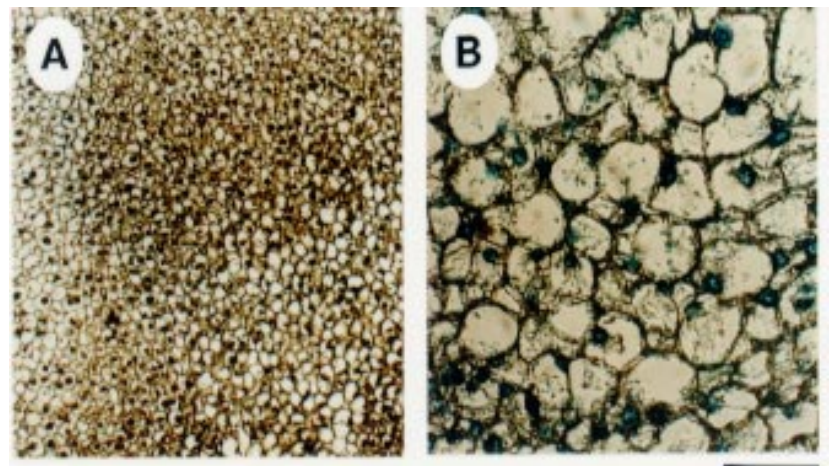

Fig. 3. Detection of apoptosis in maize embryos inoculated with Agrobacterium spp. Cross sections of embryos from genotype CG00526 (A) nontreated and (B) treated with LBA4404 $24 \mathrm{~h}$ after inoculation. Bar = $20 \mu \mathrm{m}$. 
was detected in the particulate fraction, consistent with localization within mitochondria. In contrast, in Agrobacteriuminfected cultures, cytochrome c was distributed in both the particulate and soluble fractions, reaching a maximum at $88 \mathrm{~h}$. No bands were detected in protein extracted from Agrobacterium spp. (data not shown). Concurrently, portions of each culture were simultaneously assayed for the presence of DNA laddering, providing an indication of apoptotic cell death. Cultures infected with Agrobacterium spp. displayed DNA laddering that increased over the course of infection, correlating with the level of cytochrome $\mathrm{c}$ release observed (data not shown).

The data demonstrating DNA cleavage together with the results on the distribution of cytochrome c indicated that Agrobacterium spp. could trigger the process of apoptosis in maize cells.

\section{Testing of cell death suppressor genes in maize tissues.}

Two cell death suppressor genes, p35 and iap, reported to function efficiently in vertebrates and in invertebrates were introduced into maize to test whether their expression could reduce or inhibit the effect triggered by Agrobacterium spp. on maize tissues. The coding regions of p35 and iap from baculovirus were cloned into a plant expression cassette.

In a first approach, $p 35$ and iap were cloned onto a binary vector and delivered into embryos and embryogenic calli with Agrobacterium spp. Following co-cultivation, maize tissues were examined. Tissue survival and proliferation were quantified to evaluate whether the expression of these genes had conferred protection. The results are presented in Table 2. About $25 \%$ of embryos treated with Agrobacterium spp. harboring either $p 35$ or iap gave rise to embryogenic callus whereas only $3 \%$ of embryos inoculated with a control Agrobacterium strain exhibited callus initiation. In control, approximately $80 \%$ of nontreated embryos gave rise to embryo-

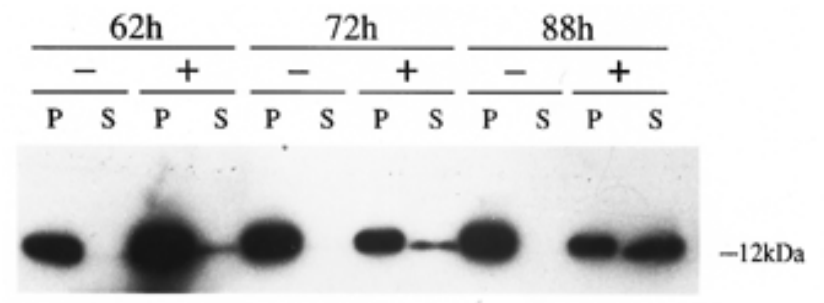

Fig. 4. Release of cytochrome $\mathrm{C}$ in cytosol after inoculation with Agrobacterium spp. Maize cells were cultured in the absence $(-)$ or presence (+) of Agrobacterium spp. for 62, 72, and $88 \mathrm{~h}$. Cells were fractionated into pellet $(\mathrm{P})$ and soluble $(\mathrm{S})$ fractions and immunoblotted with an anticytochrome c antibody. genic calli. A similar effect was observed with calli inoculated with Agrobacterium spp. harboring p35 or iap. These results suggested that $p 35$ and iap were expressed in planta and that their expression reduced tissue browning to some extent but did not completely inhibit the phenomenon. Under the conditions tested, transient expression of these genes was likely required to protect the challenged maize cells. It is also conceivable that not all challenged cells were transformed, or expressed the anti-apoptotic genes.

In a second approach, we tested whether $p 35$ and iap could prevent the Agrobacterium-induced apoptosis when stably expressed in maize callus. This assay consisted of delivering $p 35$ and iap genes under the control of a plant-expressible promoter into callus lines with the biolistic device. These constructs were co-bombarded with the pat selectable marker gene and transgenic callus lines were recovered on phosphinothricin (PPT) selection. Five transgenic callus lines were recovered from 16 pieces of calli bombarded with the pat gene only. With the same parameters, three and five callus lines were generated containing $p 35$ and iap, respectively. All the callus lines also contained the pat gene. All independent callus lines were then subjected to inoculation with Agrobacterium spp. and the number of lines surviving the treatment was recorded. A typical result of one experiment is illustrated in Table 3. Transgenic callus lines for iap and $p 35$ did not exhibit cell death after inoculation with Agrobacterium inoculation whereas control tissues exhibited cell death and failed to proliferate further. An example for iap is shown in Figure 1E. These results were reproducible on each of the callus lines.

The protective effect of $p 35$ and iap was also apparent when measured by oligonucleosomal DNA fragment electrophoresis (Fig. 5). DNA was extracted from transgenic callus following inoculation with Agrobacterium spp. as shown above. DNA fragmentation was clearly observed in calli transgenic for pat alone (Fig. 5, lanes 1-3) but not for iap ( Fig. 5, lanes 4-6) or p35 (data not shown). To further correlate expression of the cell death suppressor genes and the absence of cell death after inoculation with Agrobacterium spp., the expression of $p 35$ and iap was analyzed by reverse-transcription-polymerase

Table 3. Response to inoculation by Agrobacterium spp. of callus transgenic for $p 35$ and iap

\begin{tabular}{lcc}
\hline & \multicolumn{2}{c}{ No. of calli resistant to LBA4404 } \\
\cline { 3 - 3 } Transgenes in transformed tissues & Line 1 & Line 2 \\
\hline pUbiAc & $1 / 24(4 \%)$ & $1 / 32(3 \%)$ \\
p35, pUbiAc & $22 / 25(88 \%)$ & $25 / 28(89 \%)$ \\
iap, pUbiAc & $20 / 22(90 \%)$ & $19 / 25(76 \%)$ \\
\hline
\end{tabular}

${ }^{a}$ No. of proliferating callus pieces /no. of callus pieces tested (\%).

Table 2. Response of maize embryos and calli after inoculation with Agrobacterium spp. containing anti-apoptotic genes:

\begin{tabular}{|c|c|c|c|c|}
\hline \multirow[b]{3}{*}{ Genes tested } & \multicolumn{4}{|c|}{ Response of maize target tissues to co-cultivation with Agrobacterium spp. } \\
\hline & \multicolumn{2}{|c|}{ Embryos } & \multicolumn{2}{|c|}{ Calli } \\
\hline & Experiment no. 1 & Experiment no. 2 & Experiment no. 1 & Experiment no. 2 \\
\hline No bacteria & $52 / 63(82 \%)^{\mathrm{a}}$ & $25 / 31(80 \%)$ & $76 / 80(95 \%)^{b}$ & $72 / 80(90 \%)$ \\
\hline LBA4404 & $2 / 55(3 \%)$ & $3 / 89(3 \%)$ & $8 / 80(10 \%)$ & $6 / 80(7.5 \%)$ \\
\hline LBA4404 (p35) & $19 / 75(25 \%)$ & $18 / 74(24 \%)$ & $23 / 80(29 \%)$ & $27 / 80(33 \%)$ \\
\hline LBA4404 (iap) & $22 / 89(24 \%)$ & $21 / 75(28 \%)$ & $25 / 80(31 \%)$ & $30 / 80(37 \%)$ \\
\hline
\end{tabular}

${ }^{a}$ Number of embryos with callus initiation/number of embryos tested (\%).

${ }^{\mathrm{b}}$ Number of proliferating callus pieces /number of callus pieces tested (\%). 
chain reaction (RT-PCR). An example is shown in Figure 6. A clear band of the expected size appeared in extracts from iap and p35 transgenic callus, confirming their expression in maize. To exclude contamination of genomic DNA in the RTPCRs, control reactions were prepared in parallel. PCRs performed with the primers only in the absence of any added DNA did not amplify any fragments. Also, no band was detected if the PCR was conducted on and aliquot of mRNA after DNase treatment, or on an aliquot of reaction in which the reverse transcriptase was omitted.

\section{DISCUSSION}

This report shows that the cell death triggered by Agrobacterium spp. in maize tissues has many of the features of apoptosis. DNA fragmentation and cytological changes as well as cytochrome $\mathrm{c}$ release were shown to occur upon inoculation with Agrobacterium spp. Further evidence for Agrobacterium spp. inducing DNA fragmentation was obtained by investigating the sensitivity of the process to $\mathrm{Zn}^{2+}$ and $\mathrm{Ca}^{2+}$. Addition in the culture of $\mathrm{Ca}^{2+}$ increased the intensity of DNA ladders whereas the addition of $\mathrm{Zn}^{2+}$ markedly reduced genomic fragmentation (data not shown). These characteristics are fully consistent with the effect of these divalent cations on the endogenous endonucleases responsible for DNA cleavage during apoptosis in animal systems and in some cases in plant cells (Peitsch et al. 1993, Mittler and Lamb 1995). Whether the endonucleases induced by Agrobacterium spp. have any functional similarity with the ones induced by other pathogens remains to be determined. The intensity of the ladder was also decreased by addition of cy-

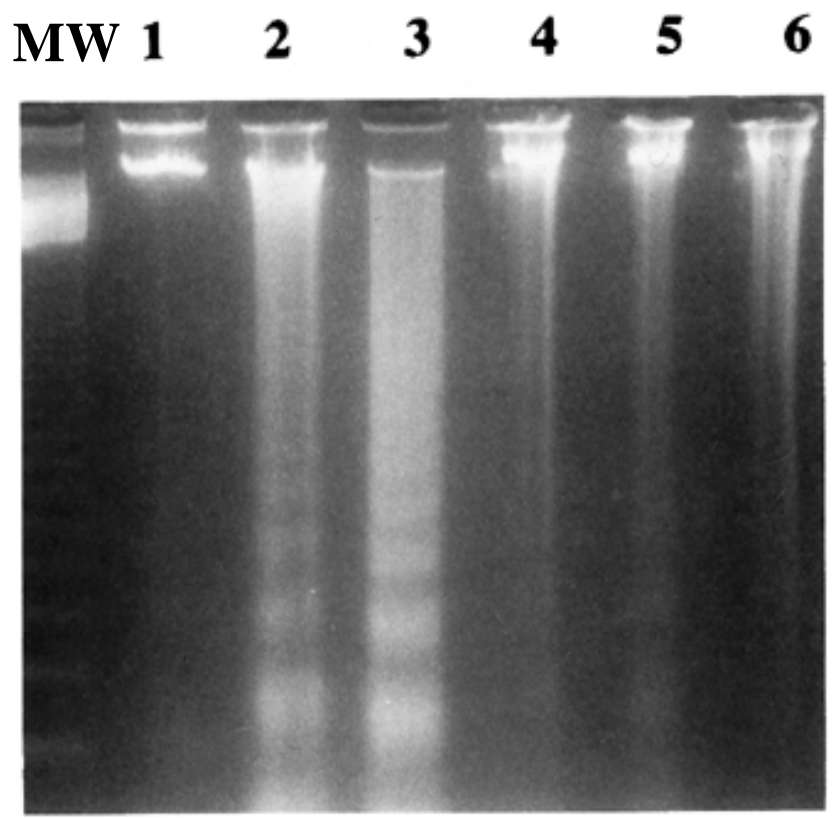

Fig. 5. Inhibition of DNA fragmentation induced by Agrobacterium spp. in maize calli transgenic for the anti-apoptotic gene. DNA was isolated from maize calli after inoculation with Agrobacterium spp. and analyzed by electrophoresis on a $2 \%$ agarose gel. Lane $1 \mathrm{~W}$, a 123-bp DNA ladder. DNA from callus transgenic for the selectable marker only (lane 1) nontreated, or treated with Agrobacterium spp. for (lane 2) 24 and (lane 3) $48 \mathrm{~h}$. DNA from callus transgenic for iap (lane 4) nontreated, or treated with Agrobacterium spp. for (lane 5) 24 and (lane 6) $48 \mathrm{~h}$. cloheximide to the medium prior to inoculation, evidence that the process requires de novo gene expression.

Two anti-apoptotic genes from baculovirus, p35 and iap, had the ability to prevent the onset of apoptosis triggered by Agrobacterium spp. in maize tissues. $p 35$ is reported to act as a direct inhibitor of caspases whereas iap may act upstream to prevent activation of caspases. Caspases drive most if not all of the terminal effector events of apoptosis in vertebrates and in invertebrates and are responsible, either directly or indirectly, for the cleavage of cellular proteins. Such proteins includes nuclear proteins such as poly(ADP-ribose) polymerase, DNA-dependent protein kinase, and lamins, as well as actin (Nagata 1997). The finding that these genes could affect the reaction of maize cells to an apoptotic stimulus strongly indicates that plants, like animals, may have caspase-like proteases regulating apoptosis. Interestingly, a caspase-like proteolytic activity was recently reported in tobacco plants undergoing an HR triggered by an infection with Tobacco mosaic virus (del Pozo and Lam 1998).

An important event in animal PCD is the release of cytochrome $\mathrm{c}$ from mitochondria into the cytosol. Cytochrome $\mathrm{c}$ release is responsible for triggering caspase activity and initiating the final degradation phase of the cell death program. In this report, cytochrome c release was observed in maize cells following exposure to Agrobacterium spp. This release correlated with DNA fragmentation and cell death. In plants, overexpression of Bax-1, involved in the release of cytochrome c in animal cells, was found to induce an HR in tobacco (Lacomme and Cruz 1999). These observations point to the possibility of a similar mechanism in both animal and plant cells.

Because p35 and iap interfere with the apoptosis phenomenon, one could expect that their expression would affect plant growth by inhibiting the PCD normally occurring during plant development. For instance, overexpression could lead to inappropriate survival of cells normally signaled to die by the pathway inhibited by 355 and iap. Although the size of the

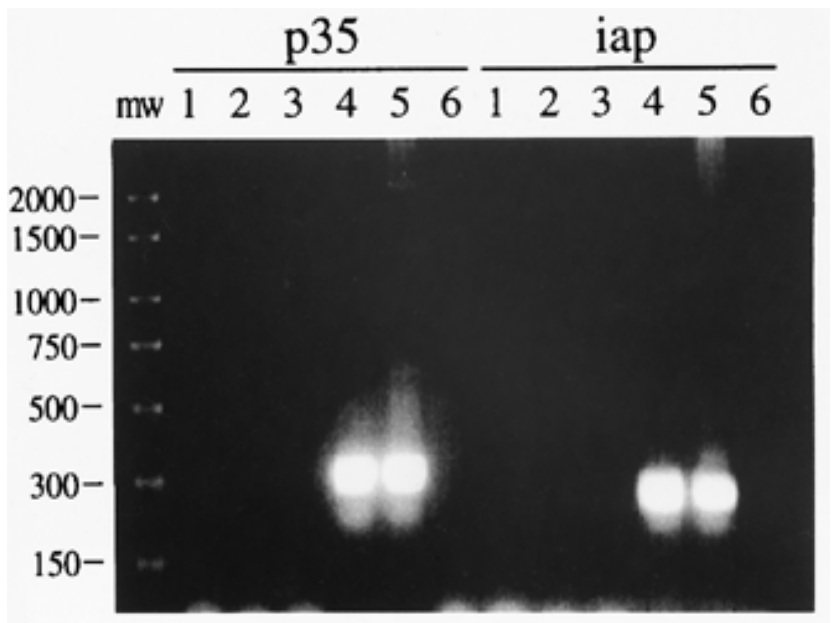

Fig. 6. Expression analysis of iap and p35 by reverse transcriptionpolymerase chain reaction (RT-PCR) in transgenic maize calli. Control PCRs were performed (lane 1) with the primers only and no DNA added, (lane 2) on an aliquot of mRNA extract after DNase treatment, (lane 3) on an aliquot of the reaction in which the reverse transcriptase was omitted, and (lane 6) on cDNA from nontransgenic calli. RT-PCR performed with (lane 4) $0.5 \mu \mathrm{g}$ of cDNA and (lane 5) $1 \mu \mathrm{g}$ of cDNA. 
experiment doesn't allow a definitive conclusion to be drawn, the phenotype of the transgenic plants was comparable to the control plants with a normal senescence pattern. This observation could be explained by (i) the presence of other factors involved in the activation of the proteases and/or the factor(s) were not totally shut off, or (ii) these particular events did not show high expression in all tissues. It is interesting to note that maize embryos inoculated with the strain containing the cell death suppressor genes often showed mixed areas of living and necrotic cells. This observation could be explained by the fact that (i) only cells transformed by the T-DNA carrying the anti-apoptotic gene survived and that the number of these cells may be small compared with the total mass of cells challenged by Agrobacterium spp.; (ii) individual transformed cells did not necessarily transmit the signal to neighboring cells; and (iii) the cell death suppressor genes rescued doomed cells very efficiently but the level of transient expression was not sufficient to confer full protection against Agrobacterium spp.

Previous work has shown that Agrobacterium spp. can transform maize even though it is generally not its natural host (Chilton 1993; Smith and Hood 1995). For instance, transgenic maize plants were recovered after inoculation of immature embryos from the inbred A188 (Ishida et al. 1996; Negrotto et al., in press). This report shows, however, that Agrobacterium spp. can trigger cell death on maize tissues of three different maize genotypes, one of them containing A188 as part of its genetic background. There may be genetic differences in susceptibility to Agrobacterium-induced PCD, as observed in other host-pathogen interactions. In addition, tissue type (embryo versus callus) may contribute to these differences in susceptibility (Lupotto et al. 1999).

Despite numerous observations that Agrobacterium spp. can induce necrosis in plant tissues from various species, there has been no previous evidence that this form of cell death proceeds via apoptosis. A molecular understanding of this mechanism may allow one to minimize Agrobacteriuminduced apoptosis and develop more efficient transformation protocols. A search for nucleosomal ladders in plant species refractory to transformation by Agrobacterium spp. will show whether apoptosis is a common outcome of incompatible Agrobacterium/plant interactions.

\section{MATERIALS AND METHODS}

\section{Maize lines.}

Friable embryogenic callus of the maize line HE/89 that is a derivative of A188 (Mórocz et al. 1990) was grown in a modified liquid N6 medium (Chu et al. 1975) amended with 500 $\mathrm{mg}$ of Bacto tryptone per liter, $30 \mathrm{~g}$ of sucrose per liter, and $0.5 \mathrm{mg}$ of 2,4-dichlorophenoxy acetic acid (2,4-D) per liter $(0.5 \mathrm{~N} 63 \mathrm{~S})$. The suspension maize proprietary cell line CG2717 was grown in N6 liquid medium supplemented with $30 \mathrm{~g}$ of sucrose per liter and $2 \mathrm{mg}$ of 2,4-D per liter (2N63S). The Nicotiana tabacum cell line NT-1 was grown in Murashige and Skoog medium (Murashige and Skoog 1962) supplemented with $2 \mathrm{mg}$ of 2,4-D per liter and sucrose (30 g/ liter) (MS3S). Suspension cultures were maintained in liquid medium on a rotary shaker (120 rpm; G10 gyrotory shaker, New Brunswick Scientific, Edison, NJ) and were subcultured every 7 days.
Embryos and nonfriable type I embryogenic callus of the maize inbred CG00526, a proprietary elite line developed from a Lancaster-type population, were used in some of the experiments. Type I calli were initiated from immature embryos $(0.8$ to $2.5 \mathrm{~mm})$ that were aseptically excised 12 to 15 days after pollination and plated scutellum up on Duncan medium supplemented with $20 \mathrm{~g}$ of sucrose per liter and $5 \mathrm{mg}$ of Chloramben per liter (5CD2S) (Koziel et al. 1993). The calli that were initiated from embryos were subcultured approximately every 2 weeks on Duncan medium supplemented with $0.5 \mathrm{mg}$ of $2,4-\mathrm{D}$ per liter $(0.5 \mathrm{D} 2 \mathrm{~S})$.

\section{Bacterial growth and Agrobacterium strains.}

Agrobacterium strains were grown for 3 days on YP medium (5 g of yeast extract per liter, $10 \mathrm{~g}$ of peptone per liter, 5 $\mathrm{g}$ of $\mathrm{NaCl}$ per liter, $15 \mathrm{~g}$ of agar per liter, $\mathrm{pH}$ 6.8) supplemented with $50 \mathrm{mg}$ of spectinomycin per liter and $10 \mathrm{mg}$ of tetracycline per liter when needed. A. tumefaciens LBA4404 (pAL4404) is a derivative of ACH5 (Ooms et al 1982). pAL4404 is a disarmed helper plasmid. A136 and C58NT1 are cured of the Ti plasmid. Bacteria were centrifuged and resuspended in the appropriate plant medium at a density ranging from $0.2 \times 10^{9}$ to $5 \times 10^{9}$ cells per ml. For the inoculation of CG2717, HE/89, CG00526, and NT-1 plant cells, bacteria were resuspended in $2 \mathrm{~N} 63 \mathrm{~S}, 0.5 \mathrm{~N} 63 \mathrm{~S}, 0.5 \mathrm{D} 2 \mathrm{~S}$, or MS3S liquid medium, respectively.

\section{Vectors for biolistic transformation.}

Vectors used to transform maize by the biolistic device were all derivatives of pUC. pUbiAc contains a plant-expressible gene encoding for the phosphinothricin acetyl transferase (PAT) conferring resistance to phosphinothricin (Wohlleben et al. 1988) driven by the maize ubiquitin promoter (Christensen et al. 1992). The coding regions of $p 35$ and iap were cloned under control of the maize metallothionein-like gene promoter (MTL) (DeFramond et al. 1991) to engineer pNOV122 and pNOV 123, respectively. The $p 35$ coding region was cloned as a PstI-EcoRI fragment from pHSP35VI ${ }^{+}$(Clem and Miller 1994). The iap coding region was cloned as an SalI-SpeI fragment from pHSCpIAPVI ${ }^{+}$(Clem and Miller 1994).

\section{Vectors for transformation by Agrobacterium spp.}

p35 and iap from pNOV122 and pNOV123 were cloned between the border sequences into the binary vector pSB11 (Ishida et al. 1996). These vectors were then introduced into LBA4404 (pAL4404, pSB1) by electroporation.

\section{Transformation by bombardment.}

Plasmid DNA was precipitated onto 0.3 to $1 \mu \mathrm{m}$ of gold microcarrier as described in the DuPont Biolistic manual (du Pont de Nemours, Wilmington, DE). Two micrograms of pNOV122 or pNOV123 and $2 \mu$ g of pUbiAc were used per 50 $\mu \mathrm{l}$ of microcarrier. Maize calli (eight pieces per plate) were bombarded with the PDS-1000/He biolistic device. Tissues were placed on the shelf $8 \mathrm{~cm}$ below the stopping screen shelf and a $10 \times 10 \mu \mathrm{m}$ stainless steel screen was used with rupture disks of $650 \mathrm{lb} / \mathrm{in}^{2}$ value. After bombardment, tissues were selected on $100 \mathrm{mg}$ of PPT per liter. Six to 8 weeks later, tissues were transferred onto $40 \mathrm{mg}$ of PPT per liter. Transgenic tissues were either used directly for inoculation experiments or transferred onto regeneration medium (Murashige and 
Skoog medium containing 3\% sucrose, $0.25 \mathrm{mg}$ of ancymitol per liter and $5 \mathrm{mg}$ of kinetin per liter) with $16 \mathrm{~h}$ of light per day. Putative transgenic plants were analyzed by PCR and further by RT-PCR (see below).

\section{Inoculation of maize embryos and transgenic callus lines with Agrobacterium spp.}

Embryos were inoculated with Agrobacterium spp. at a density of 0.2 to $1 \times 10^{9}$ cells per $\mathrm{ml}$ for $5 \mathrm{~min}$ and then cocultured on the callus initiation medium for 3 days. Tissues were then transferred on the same medium supplemented with cefotaxime ( $250 \mathrm{mg} / \mathrm{liter})$. Transgenic callus lines obtained as described above were inoculated with Agrobacterium spp. by soaking them in bacterial suspension for 5 to $10 \mathrm{~min}$. After inoculation, maize tissues were co-cultured in the dark at $25^{\circ} \mathrm{C}$ on $0.5 \mathrm{D} 2 \mathrm{~S}$. Tissues were transferred on the same medium supplemented with cefotaxime ( $250 \mathrm{mg} / \mathrm{liter}) 2$ or 3 days after inoculation. All experiments were conducted three times.

For all experiments, the effect of Agrobacterium spp. on callus lines and on embryos was quantified by measuring the weight 2 weeks after co-culture. At this stage, about $90 \%$ of control embryos have produced calli from the scutellum of the embryo and control callus lines have proliferated and doubled in size.

\section{Iinoculation of suspension cells with Agrobacterium spp.}

Friable embryogenic callus of CG2717, HE/89, and NT-1 maintained in $50 \mathrm{ml}$ of liquid medium was incubated with Agrobacterium spp. for $10 \mathrm{~min}$ or $1 \mathrm{~h}, 24$, or $48 \mathrm{~h}$ prior to transfer to cefotaxime-containing medium. Fifty microliters of a bacterial suspension $\left(0.2 \times 10^{9}\right.$ or $2 \times 10^{9}$ cells per ml $)$ was added to $10 \mathrm{ml}$ of tissue culture medium containing $1 \mathrm{ml}$ of packed cell volume. If the culture was to be incubated longer than 2 days, bacteria were washed off and plant cells were resuspended in the same medium supplemented with cefotaxime (250 mg/liter).

In one experiment, maize suspension cells were inoculated with Agrobacterium spp. as described above and the cocultivation lasted $48 \mathrm{~h}$. Maize cells were then centrifuged and washed three times with liquid culture medium containing cefotaxime $(250 \mathrm{mg} /$ liter $)$. The cells were resuspended in $10 \mathrm{ml}$ of fresh medium and placed in a petri dish. The cells were covered either with a filter paper 3MM (Whatman International, Springfield Mill, Kent, UK) or with a $200 \times 200$ stainless steel mesh with 200 openings per linear $2.54 \mathrm{~cm}$ horizontally and vertically (McMaster-Carr, New Brunswick, NJ). About $1 \mathrm{ml}$ of fresh maize cells was placed on the top of the filter or mesh. Alternatively, treated maize cells were embedded in $0.5 \%$ low melting agar (Seaplaque; FMC, Rockland, $\mathrm{ME}$ ) and poured in a $250-\mathrm{ml}$ flask. About $1 \mathrm{ml}$ of fresh maize cells grown in $50 \mathrm{ml}$ of liquid medium supplemented with cefotaxim was added to the flask.

\section{Analysis of transgenic material.}

Genomic DNA was extracted from $100 \mathrm{mg}$ of callus with a DNA extraction kit (Isoquick; Orca Research, Bothwell, WA) and resuspended in $20 \mu \mathrm{l}$ of water. One microliter was used for PCR. PCRs were performed in a Perkin-Elmer Cetus thermal cycler (Norwalk, CT). Each $25-\mu 1$ reaction contained $1 \times$ PCR buffer, $0.5 \mathrm{U}$ of AmpliTaq DNA polymerase (Roche, Branchburg, NJ), $200 \mu \mathrm{M}$ concentrations of each dNTP, and
$0.2 \mu \mathrm{M}$ concentrations of each primer. To detect the presence of the pat gene in tissues, PCRs were performed with the primers PAT1 and PAT2. The primer set used to detect iap was $\mathrm{P}$ and $\mathrm{I}$. The primer set $\mathrm{P}$ and 35 was used to detect $p 35$ in transgenic callus lines. All reactions were conducted at an annealing temperature of $55^{\circ} \mathrm{C}$ for 35 cycles.

PAT1: 5'-TGTCTCCGGAGAGGAGACC -3';

PAT2: 5'- CCAACATCATGCCATCCACC-3';

MTL (P): 5'-AGGTGTCCATGGTGCTCAAG-3';

iap (I): 5'-ACAATCGAACCGCACACGTC-3';

p35 (35): 5'-CCAGGTAGCAGTCGTTGTGT-3'

\section{p35 and iap RT-PCR.}

Total RNA was extracted from transgenic callus with Tripure Isolation Reagent (Boehringer Mannheim, Mannheim, Germany). RNA was treated with RNase-free DNase, and 0.5 $\mu \mathrm{g}$ was utilized for cDNA synthesis with Advantage RT-PCR (Clontech, Palo Alto, CA) and oligo-dT primer. After the second-strand synthesis, one-twentieth of the reaction was used as a template for PCR with Taq DNA polymerase. $p 35$ primers used for RT-PCR were as follows: 5'-GGTCCTATACGAAG CGTTAC and 5'-CCACGTAGCAGTCGTTGTGT, which amplifies $300 \mathrm{bp}$ of transcript. iap primers were 5'-CATGT CTGACTTGCGATTGG and 5'-ACAATCGAACCGCACAC GTC, which amplifies 248 bp of transcript. All reactions were conducted at an annealing temperature of $55^{\circ} \mathrm{C}$ for 30 cycles.

\section{DNA extraction for DNA fragmentation detection.}

Cells were removed at various times after inoculation with Agrobacterium spp. and chromosomal DNA was isolated as described by Hall et al. (1991). DNA was extracted from 0.5, 0.5 , and $1 \mathrm{~g}$ of cells from NT1, CG2717, and HE/89, respectively. Approximately 1 to $2 \mu \mathrm{g}$ of undigested genomic DNA sample was run on a $2 \%$ agarose gel containing $0.1 \mu \mathrm{g}$ of ethidium bromide per $\mathrm{ml}$.

\section{In situ cytological detection of DNA fragmentation.}

The assay involves end-labeling the DNA fragments by the Klenow enzyme with biotylated nucleotides that are conjugated to a detectable marker such as streptavidin fluorescein. Increased DNA fragmentation leads to a staining of the nucleus. Embryos were soaked in $3.7 \%$ formaldehyde solution and processed as described by the manufacturer (Trevigen, Gaithersburg, MD). To detect genomic DNA cleavage in situ, fixed embryos were treated with the TACS-1 kit (Trevigen). Fixed cross sections were first treated with proteinase $\mathrm{K}$ for 5 min at room temperature and then dipped for $5 \mathrm{~min}$ into $2 \%$ hydrogen peroxide to remove endogenous peroxidase. After a brief wash with Klenow buffer, tissues were incubated for $1 \mathrm{~h}$ at $37^{\circ} \mathrm{C}$ with the Klenow enzyme. A dark, insoluble precipitate indicative of apoptosis formed in individual cells and could be detected microscopically (Cullivier 1996).

\section{Cytochrome c distribution.}

Maize suspension cells (CG2717) were incubated in the presence or absence of A. tumefaciens LBA4404 (approximately $4 \times 10^{8}$ cells per $\mathrm{ml}$ at $T=0$ ) for 62,72 , and $88 \mathrm{~h}$, and cytochrome c distribution was analyzed as described previously (Stein and Hansen 1999). A portion of each culture was fractionated into particulate $(\mathrm{P})$ containing mitochondria and soluble $(\mathrm{S})$ fractions containing the cytosol. Fractions 
were immunoblotted with the mouse monoclonal antibody clone $7 \mathrm{H} 8.2 \mathrm{C} 12$ at a concentration of $2 \mu \mathrm{g} / \mathrm{ml}$ (PharMingen, San Diego, CA) as follows: cells were washed and suspended in mitochondria isolation buffer $(50 \mathrm{mM}$ Tris $\mathrm{pH} 7.5 ; 10 \mathrm{mM}$ $\mathrm{MgCl}_{2} ; 1 \mathrm{mM} \mathrm{CaCl} 2 ; 1 \mathrm{mM}$ EDTA; $0.25 \mathrm{M}$ sucrose; $1 \mathrm{mM}$ AEBSF; $2 \mu \mathrm{g}$ of pepstatin A per $\mathrm{ml}(\mathrm{wt} / \mathrm{vol}) ; 10 \mu \mathrm{g}$ of leupeptin per $\mathrm{ml}(\mathrm{wt} / \mathrm{vol}) ; 10 \mu \mathrm{g}$ of aprotinin per $\mathrm{ml}(\mathrm{wt} / \mathrm{vol})$; $0.1 \%$ (vol/vol) Antifoam 204) and homogenized with a polytron. The homogenate was filtered through Miracloth (Calbiochem, San Diego, CA) and centrifuged at $1,000 \times g$ for $10 \mathrm{~min}$. The resulting supernatant was centrifuged at $10,000 \times$ $g$ for $10 \mathrm{~min}$ and the particulate fraction residing in the pellet was resuspended in mitochondria isolation buffer. The supernatant was further centrifuged at $100,000 \times g$ for $30 \mathrm{~min}$ to obtain a soluble fraction in the supernatant. Protein concentration was assayed by the Bradford method (Bio-Rad, Hercules, CA) and $5 \mu \mathrm{g}$ of protein was loaded per lane on a 4 $20 \%$ polyacrylamide gel (Mark 12; Novex, Frankfurt, Germany). The gel was electrophoresed in the presence of sodium dodecyl sulfate and dithiothreitol, and electroblotted onto a polyvinylidene difluoride membrane (Immobilon; Millipore, Bedford, MA). The blot was developed with a chemiluminescent substrate (Supersignal; Pierce, Rockford, IL) according to the manufacturer's instructions.

\section{ACKNOWLEDGMENTS}

I would like to thank Lois $\mathrm{K}$. Miller for providing the clones pHSP35 $\mathrm{VI}^{+}$and $\mathrm{pHSCpIAPVI}{ }^{+}$, Joshua Stein for conducting the experiment on cytochrome c localization, and Allan Wenck for critical reading of the manuscript.

\section{LITERATURE CITED}

Armstrong, C. L. 1999. The first decade of maize transformation: A review and future perspective. Maydica 44:101-109.

Baker, B., Zambryski, P. C., Staskawicz, B., and Dinesh-Kumar, S. P. 1997. Signaling in plant microbe interactions. Science 276:726-733.

Binns, A. N., and Thomashow, M. F. 1988. Cell biology of Agrobacterium infection and transformation of plants. Annu. Rev. Microbiol. 42:575-606.

Birnbaum, M. J., Clem, R. J., and Miller, L. K. 1994. An apoptosisinhibiting gene from a nuclear polyhedrosis virus encoding a polypeptide with Cys/His sequence motifs. J. Virol. 68:2521-2528.

Buckner, B., Janick-Buckner, D., Gray, J., and Johal, G. S. 1998. Celldeath mechanisms in maize. Trends Plant Sci. 3:218-223.

Bump, N. J., Hackett, M., Hugunin, M., Seshagiri, S., Brady, K., Chen, P., Ferenz, C., Franklin, S., Ghayur, T., and Li, P. 1995. Inhibition of ICE family proteases by baculovirus antiapoptotic protein p35. Science 269:1885-1888.

Cahoon, R. E., and Klein, T. M. 1999. Inhibitors of apoptosis in plants. PCT patent application WO 99/47688 (on-line).

Chilton, M.-D. 1993. Agrobacterium gene transfer: Progress on a "poor man's vector" for maize. Proc. Natl. Acad. Sci. USA 90:3119-3120.

Christensen, A. H., Sharrock, R. A., and Quail, P. H. 1992. Maize polyubiquitin genes: Structure, thermal perturbation of expression and transcript splicing, and promoter activity following transfer to protoplasts by electroporation. Plant Mol. Biol. 18:675-689.

Chu, C. C., Wang, C. C., Sun, C. S., Hsu, C., Yin, K. G., Chu, C. Y., and Bi, F. Y. 1975. Establishment of an efficient medium for anther culture of rice through comparative medium on the nitrogen sources. Sci. Sinica. 18:659-668.

Clem, R. J., Fechheimer, M., and Miller, L. K. 1991. Prevention of apoptosis by a baculovirus gene during infection of insect cells. Science 254:1388-1390.

Clem, R. J., and Miller, L. K. 1994. Control of programmed cell death by the baculovirus genes p35 and iap. Mol. Cell. Biol. 14:5212-5222.
Crook, N. E., Clem, R. J., and Miller, L. K. 1993. An apoptosisinhibiting baculovirus gene with a zinc finger-like motif. J. Virol. 67: 2168-2174.

Cullivier, O., Pirianov, G., Kleuser, B., Vanek, P. G., Coso, O. A., Gutking, J. S., and Spiegel, S. 1996. Suppression of ceramide-mediated programmed cell death by sphingosine-1-phosphate. Nature 381:800803.

de Block, M. 1990. Factors influencing the tissue culture and the Agrobacterium tumefaciens-mediated transformation of hybrid aspen and poplar clones. Plant Physiol. 93:1110-1116.

De Cleene, M., and De Ley, J. 1976. The host range of crown gall. Bot. Rev. 42:389-466.

DeFramond, A. 1991. A metallothionein-like gene from maize (Zea mays). Cloning and characterization. FEBS Lett. 290:103-106.

del Pozo, O., and Lam, E. 1998. Caspases and programmed cell death in the hypersensitive response of plants to pathogens. Curr. Biol. 8: 1129-1132.

Deng, W., Pu, X., Goodman, R. N., Gordon, M. P., and Nester, E. W. 1995. T-DNA genes responsible for inducing a necrotic response on grape vines. Mol. Plant-Microbe Interact. 8:538-548.

Ellis, R. E., Yuan, J., and Horvitz, H. R. 1991. Mechanisms and functions of cell death Annu. Rev. Cell. Biol. 7:663-698.

Gilchrist, D. G. 1998. Programmed cell death in plant disease: The purpose and promise of cellular suicide. Annu. Rev. Phytopathol. 36:393414.

Goldstein, P. 1997. Controlling cell death. Science 275:1081-1082.

Greenberg, J. T. 1997. Programmed cell death in plant-microbe interactions. Annu. Rev. Plant Physiol. Plant Mol. Biol. 48:525-545.

Hall, G., Allen, G. C., Loer, D. S., Thompson, W. F., and Spiker, S. 1991. Nuclear scaffolds and scaffold-attachment regions in higher plants. Proc. Natl. Acad. Sci. USA 88:9320-9324.

Hansen, G., and Chilton M.-D. 1999. Lessons in gene gransfer to plants by a gifted microbe. Pages 21-57 in: Current Topics in Microbiology and Immunology. Vol. 240. Plant Biotechnology: New Products and Applications. J. Hammond, P. B. McGarvey, and V. Yusibov, eds. Springer-Verlag, Berlin.

Hansen, G., Das, A., and Chilton, M.-D. 1994. Constitutive expression of the virulence genes improves the efficiency of plant transformation by Agrobacterium. Proc. Natl. Acad. Sci. USA 91:7603-7607.

Hansen, G., and Wright, M. S. 1999. Recent advances in the transformation of plants. Trends Plant Sci. 4:226-231.

Ishida, Y., Saito, H., Ohta, S., Hiei, Y., Komari, T., and Kumashiro, T. 1996. High efficiency transformation of maize (Zea mays L.) mediated by Agrobacterium tumefaciens. Nat. Biotechnol. 14:745-750.

Jones, A. M., and Dangl, J. L. 1996. Logjam at the Styx: Programmed cell death in plants. Trends Plant Sci. 1:114-119.

Koziel, M. G., Beland, G. L., Bowman, C., Carozzi, N. B., Crenshaw, R., Crossland, L., Dawson, J., Desai, N., Hill, M., Kadwell, S., Launis, K., Lewis, K., Maddox, D., McPherson, K., Meghji, M. R., Merlin, E., Rhodes, R., Warren, G. W., Wright, M., and Evola, S. V. 1993. Field performance of elite transgenic maize plants expressing an insecticidal protein derived from Bacillus thuringiensis. Bio/Technology 11:194-200.

Kumar, S., and Colussi, P.A. 1999. Prodomains - adaptors - oligomerization: The pursuit of caspase activation in apoptosis. Trends Biochem. Sci. 24:1-4.

Lacomme, C., and Cruz, S. S. 1999. Bax-induced cell death in tobacco is similar to the hypersensitive response. Proc. Natl. Acad. Sci. USA 96:7956-7961.

Levine, A., Pennell, R. I., Alvarez, M. E., Palmer, R., and Lamb, C. 1996. Calcium-mediated apoptosis in a plant hypersensitive disease resistance response. Curr. Biol. 6:427-437.

Lupotto, E., Realli, A., Passera, S., and Chan, M.-T. 1999. Maize elite lines are susceptible to Agrobacterium tumefaciens-mediated transformation. Maydica 44:211-218.

Miller, L. K. 1999. An exegesis of IAPs: Salvation and surprises from BIR motifs. Trends Cell Biol. 9:323-328.

Mittler, R., and Lam, E. 1995. Identification, characterization, and purification of a tobacco endonuclease activity induced upon hypersensitive response cell death. Plant Cell 7:1951-1962.

Mórocz, S., Donn, G., Németh, J., and Dudits, D. 1990. An improved system to obtain fertile regenerants via maize protoplasts isolated from a highly embryogenic suspension culture. Theor. Appl. Genet. 80:721-726. 
Murashige, T., and Skoog, F. 1962. A revised medium for rapid growth and bioassays with tobacco tissue cultures. Physiol. Plant. 15:473-497.

Nagata, S. 1997. Apoptosis by death factor. Cell 85:817-827.

Narasimhulu, S. B., Deng, X.-B., Sarria, R., and Gelvin, S. B. 1996. Early transcription of Agrobacterium T-DNA genes in tobacco and maize. Plant Cell 8:873-886.

Negrotto, D. N., Jolley, M., Beer, S., Wenck, A. R., and Hansen, G. The use of phosphate-6-mannose isomerase as a selectable marker to recover transgenic maize plants (Zea mays L.) via Agrobacterium transformation. Plant Cell Rep. (In press.)

Ooms, G., Hooykaas, R., Van Veen, R. J. M., Van Beelen, P., Regensburg-Tuïnk, T. J. G., and Schilperoort, R. A. 1982. Octopine Tiplasmid deletion mutants of Agrobacterium tumefaciens with emphasis on the right side of the T-region. Plasmid 7:15-29.

Peitsch, M. C., Polzar, B., Stephan, H., Crompton, T., MacDonald, H R., Mannherz, H. G., and Tschopp, J. 1993. Characterization of the endogenous deoxyribonuclease involved in nuclear DNA degradation during apoptosis (programmed cell death). EMBO J. 12:371-377.

Perl, A., Lotan, O., Abu-Abied, M., and Holland, D. 1996. Establishment of an Agrobacterium-mediated transformation system for grape (Vitis vinifera L.): the role of antioxidants during grape-Agrobacterium interactions. Nat. Biotechnol. 14:624-628.

Pennell, R. I., and Lamb, C. 1997. Programmed cell death in plants. Plant Cell 9:1157-1168.

Raff, M. 1998. Cell suicide for beginners. Nature 396:119-122.

Reed, J. C. 1997. Cytochrome c: Can't live with it - can't live without it. Cell 91:559-562.
Smith, R. H, and Hood, E. 1995. Agrobacterium tumefaciens transformation of monocotyledons. Crop Sci. 35:301-309.

Solomon, M., Belenghi, B., Delledone, M., Menachem, E., and Levine, A. 1999. The involvement of cysteine proteases and protease inhibito genes in the regulation of programmed cell death in plants. Plant Cell 11:431-443.

Stein, J., and Hansen, G. 1999. Mannose induces an endonuclease responsible for DNA laddering in plant cells. Plant Physiol. 1211:71-80.

Teodoro, J. G., and Branton, P. E. 1997. Regulation of apoptosis by viral gene products. J. Virol. 71:1739-1746.

Wohlleben, W., Arnold, W., Broer, I., Hillemann, D., Strauch, E., and Puhler, A. 1988. Gene nucleotide sequence of the phosphinothricin $N$ acetyltransferase gene from Streptomyces viridochromogenes Tu494 and its expression in Nicotiana tabacum. Gene 15:25-37.

Wolf, B. B., and Green, D. R. 1999. Suicidal tendencies: apoptotic cell death by caspase family proteinases. J. Biol. Chem. 274:2004920052.

Yanofsky, M., Lowe, B., Montaya, A., Rubin, R., Krul, W., Gordon, M., and Nester, E. W. 1985 Molecular and genetic analysis of factors controlling host range in Agrobacterium tumefaciens. Mol. Gen. Genet. 201:237-246.

Yanofsky, M. F., and Nester, E. W. 1986. Molecular characterization of a host-range-determining locus from Agrobacterium tumefaciens. J. Bacteriol. 168:237-243.

Zupan, J. R,, Citovsky, V., and Zambryski, P. 1996. Agrobacterium VirE2 protein mediates nuclear uptake of single-stranded DNA in plant cells. Proc. Natl. Acad. Sci. USA 93:2392-2397. 